Article

\title{
Impact of Ginger Root Powder Dietary Supplement on Productive Performance, Egg Quality, Antioxidant Status and Blood Parameters in Laying Japanese Quails
}

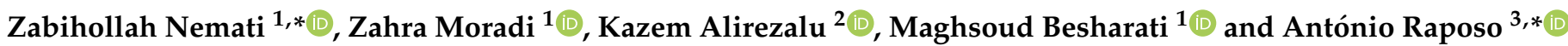 \\ 1 Department of Animal Science, Ahar Faculty of Agriculture and Natural Resources, University of Tabriz, \\ Tabriz 5166616471, Iran; zahra.moradi81@yahoo.com (Z.M.); m_besharati@hotmail.com (M.B.) \\ 2 Department of Food Science and Technology, Ahar Faculty of Agriculture and Natural Resources, \\ University of Tabriz, Tabriz 5166616471, Iran; kazem.alirezalu@tabrizu.ac.ir \\ 3 CBIOS (Research Center for Biosciences and Health Technologies), Universidade Lusófona de Humanidades \\ e Tecnologias, Campo Grande 376, 1749-024 Lisboa, Portugal \\ * Correspondence: znnemati@yahoo.com or znemati@tabrizu.ac.ir (Z.N.); antonio.raposo@ulusofona.pt (A.R.)
}

Citation: Nemati, Z.; Moradi, Z.; Alirezalu, K.; Besharati, M.; Raposo, A. Impact of Ginger Root Powder Dietary Supplement on Productive Performance, Egg Quality,

Antioxidant Status and Blood Parameters in Laying Japanese Quails Int. J. Environ. Res. Public Health 2021, 18, 2995. https://doi.org/10.3390/ ijerph18062995

Academic Editors: María José Benito and Paul B. Tchounwou

Received: 9 January 2021

Accepted: 11 March 2021

Published: 15 March 2021

Publisher's Note: MDPI stays neutral with regard to jurisdictional claims in published maps and institutional affiliations.

Copyright: (c) 2021 by the authors. Licensee MDPI, Basel, Switzerland. This article is an open access article distributed under the terms and conditions of the Creative Commons Attribution (CC BY) license (https:// creativecommons.org/licenses/by/ $4.0 /)$

\begin{abstract}
Medicinal plants with antibacterial effects have been used by humans for centuries. In the recent decade, due to the development of antibiotic resistant strains, many studies have focused on the use of natural compounds as feed additives in livestock. Ginger, among all, have repetitively shown numerous biological activities, antibacterial, and antibiotic properties. This study was conducted to evaluate the effects of ginger root powder (GP) on the performance, egg quality, and blood parameters of Japanese quail. A total of 240 10-weeks old female quails were used in a completely randomized design with 4 treatments, 4 replicates, and 15 birds per replicate. Dietary treatment were basal diet (control) and basal diet containing $0.5,1$, and $1.5 \mathrm{~g} / \mathrm{kg}$ of ginger root powder. Growth performance and exterior and interior quality of egg were measured biweekly over eight-week period. At the end of experiment blood parameters were evaluated. The results showed that diet supplementation with different levels of GP had no significant effect on egg production, egg mass weight, and egg weight $(p>0.05)$. However, feed intake and feed conversion ratio were significantly lower in the treatment group than the control in the whole period $(p<0.05)$. Egg Quality traits (shape index, albumen index, the percentage of albumen, yolk and shell, yolk $\mathrm{pH}$, and shell thickness and strength) were not affected by the supplements in the whole trial period. Addition of GP significantly increased the albumen height, Haugh unit, and albumen $\mathrm{pH}$ in comparison with the control treatment $(p<0.05)$. GP reduced blood triglyceride level yet was ineffective on blood total antioxidant capacity and malondialdehyde. In conclusion, dietary supplementation with GP, could improve productive performance and the egg quality of Japanese quails. Nonetheless a comprehensive study needs to be performed in order to evaluate the impact of quail dietary ginger supplementation on productive performance and egg quality and their stability during storage time for commercial use.
\end{abstract}

Keywords: antioxidant; egg quality traits; ginger; immunity; Japanese quail performance

\section{Introduction}

Today, many phytochemical rich medicinal herbs are considered as potential alternatives to antibiotics and growth promoters due to the ban of antibiotics use in livestock in the European union [1]. Aromatic plants have been successfully used to improve antioxidant capacity in poultry industry [2,3]. Ginger (zingiber officinale roscoe) belongs to the Zingiberaceae family, including 47 genera and 1400 species [4]. Ginger is a native tropical plant in Southeast Asia and its commercial cultivation is not limited to Asia as is grown worldwide [4]. The global production of ginger was 3.3 million tons in 2016 [5]. The ginger can be consumed as fresh produce, dehydrated, and or processed product. Fresh rhizome is widely used as a spice and food condiment whether in the form of powder, extract, 
supplement, and or medicine [6]. Not only that the ginger rhizome is nutrient rich (amino acids, fatty acids, vitamins, and minerals) but the produce also contains compounds such as gingerol, gingerdiol, gingerdione, and shagaol that are potent intestinal mucous membrane and digestion stimulators [7]. The gingerols and shagaols are responsible for the pungency of fresh ginger and dried ginger, respectively [8].Ginger containing different phenolic component and they exhibited many bioactivities such as antioxidant [9], anti-anxiety [10], anti- Nausea [11], anti-inflammation [12], glucose-lowering [13], and health benefiting effects by reducing free radicals damage and improving cardiovascular status [14,15]. Furthermore, ginger is used for its various medicinal properties and alleviation and treatment of different symptoms such as animal mycotoxicosis [16], vomiting, pain, indigestion, and upper respiratory tract infection [17].

Throughout the production of ginger drink, powder, flakes and or ginger extract, significant amount of process discards, and byproducts are produced every year that could potentially be used as inexpensive feed additive in animal industry $[18,19]$. In a recent study, ginger supplement in broiler chicken diets stimulated the immune and digestive systems of the birds considerably [20]. In another study, Yusuf et al. [21] showed that, ginger in combination with probiotic and organic acid (citric acid) in laying Japanese quail diets improved the laying performances, feed conversion ratio (FCR), egg quality, bone characteristics, and reproductive indexes. Accordingly, diet supplementation with ginger powder increased total superoxide dismutase and glutathione peroxidase (Gpx) activities while it reduced malondialdehyde (MDA) and cholesterol concentrations in serum of broiler chickens at 21 and 42 days of age [22]. Ginger has also been reported to increase gastrointestinal secretion, digestive enzymes, improve circulation and intestinal movements [23]. It has been reported that using 4 and $8 \mathrm{~g} / \mathrm{kg}$ of ginger powder of diet reduced feed intake but improved weight gain compared with control group [24]. In a study, ginger powder at $0.05 \mathrm{~g} / \mathrm{kg}$ of diet, increased the egg production, hatching, reproductive performance, and economic efficiency of Japanese quail [25]. Other studies have reported that the addition of ginger essential oils at $300 \mu \mathrm{L} / \mathrm{kg}$ of diet, increased egg shell weight and shell thickness in laying hens [26]. Supplementation of broiler chickens diet with ginger reduced MDA and cholesterol concentration in serum of chickens at 21 and 42 days of age [22]. The effects of ginger supplementation in diets of broiler chicks at 64 weeks of age at $0.2,0.4$, and $0.6 \%$ showed a significant improvement in the feed conversion ratio in the treatment group containing $0.4 \%$ ginger powder [25]. Ibtisham et al. [27] have shown improvement of the production rate and feed intake of ginger powder and Chinese herbal medicine fed laying hens. They also concluded that ginger powder could be a suitable alternative to the antibiotic in poultry feed. In another study, Habibi et al. [28] reported that ginger powder and essential oils may be a vital replacement for synthetic antioxidants in broiler diets. Additionally, these researchers stated that ginger powder might be better than extracted essential oil for improving antioxidant status in broiler. The effect of diet supplementation with extract from thyme and ginger on the egg quality of laying hen was investigated by Damaziak et al. [29], who demonstrated that hen diet supplementation was improved Haugh unit of albumen and yolk color of fresh and hard boiled eggs. Recent studies suggest that Haugh unit and yolk color are important in the commercial production of table eggs which affected by dietary composition (e.g., protein sources and pigments) [30]. Color is an important qualitative feature of food acceptability as it affects consumers' perceptions of quality and flavor helping those making decisions about the purchase. Most consumers find yolk color related to the age and health of the animal and the quality of egg and its derivatives. Generally, edible additives and feeding methods are the main factors in the egg yolk color. For instance, natural pigments of plants such as carotenoids play an important role in the development of egg yolk color [25]. However, to the best of our knowledge, information regarding the potential benefits of these feed additive in the Japanese quail's diet is limited, so the present study was conducted to evaluate the effects of using different levels of ginger powder on the productive performance, eggs quality, and blood parameters in laying Japanese quails. 


\section{Materials and Methods}

Animal welfare statement: All the methods and protocols used in this study were approved by the Research Bioethics Committee of Tabriz University (RBCT) for Use of Laboratory Animals of University of Tabriz (Approved number: IR.TABRIZU.REC.1399.032).

\subsection{Experimental Birds and Management}

A total of 240 laying Japanese quails (10 weeks old), after a two-week adaptation period, were randomly divided into 4 experimental groups (4 replicates each, 15 birds per pen). Dietary groups included the basal diet (control) and the basal diet supplemented with $0.5,1$, and $1.5 \mathrm{~g}$ ginger root powder per $\mathrm{kg}$ of diet. The birds were kept in a multi-story wired cages in a well-ventilated room with the temperature of $23-29^{\circ} \mathrm{C}$ and $16 \mathrm{~L}: 8 \mathrm{D}$ light regime during experiment. Each cage had $3600 \mathrm{~cm}^{2}$ floor space with size $45 \times 45 \mathrm{~cm}^{2}$ and was equipped with two nipple drinker and one feeder. The basal diet was formulated to meet the National Research Council (NRC) recommendations [31] as showed in Table 1. Quails received water and feed ad libitum throughout the experimental period.

Table 1. Ingredient and composition of the basal diet.

\begin{tabular}{cccc}
\hline Item & Value (\%) & Diet Composition & Value \\
\hline Corn & 45.38 & ME (kcal/kg) & 2900 \\
Soybean meal & 32.50 & Crude protein $(\%)$ & 20 \\
Wheat bran & 10.51 & Ca $(\%)$ & 2.5 \\
Soybean oil & 3.2 & Available P (\%) & 0.39 \\
Di calcium phosphate & 1.8 & Na & 0.15 \\
Calcium carbonate & 5.3 & Methionine (\%) & 0.7 \\
Methionine & 0.39 & Lysine $(\%)$ & 0.34 \\
Sodium chloride & 0.32 & Sys $(\%)$ & \\
Bicarbonate $^{1}$ & 0.1 & & \\
Vitamin $^{1}$ & 0.3 & & \\
Trace mineral $^{2}$ & 0.3 & & \\
\hline
\end{tabular}

${ }^{1}$ Supplied per kg of feed: vitamin B1, $2.16 \mathrm{mg}$; vitamin B2, $7.92 \mathrm{mg}$; pantothenic acid, $12 \mathrm{mg}$; nicotinic acid;36, vitamin B6, $3.6 \mathrm{mg}$; folic acid, $1.2 \mathrm{mg}$; biotin, $0.12 \mathrm{mg}$; vitamin K3, $2.4 \mathrm{mg}$; vitamin E, 21.6 IU; chloin chloride, 300 ; antioxidant, $120 \mathrm{mg}$; vitamin A, 10,800 IU; vitamin D3, $2400 \mathrm{IU}$ and vitamin B12, $0.018 \mathrm{mg} .{ }^{2}$ Supplied per kg feed: $\mathrm{FeSO}_{4}, 0.15 \mathrm{~g} ; \mathrm{MnSO}_{4}, 0.12 \mathrm{~g} ; \mathrm{CuSO}_{4}, 0.03 \mathrm{~g} ; \mathrm{I}, 1.2 \mathrm{mg}$ and $\mathrm{Se}, 0.24 \mathrm{mg}$.

\subsection{Preparation of Ginger Powder Samples}

Fresh ginger root was purchased from the local market and then cut into slices. Ginger slices were air-dried (sunshade for 1 day) at room temperature and further oven-dried (at $40{ }^{\circ} \mathrm{C}$ for $40 \mathrm{~h}$ ) (Memmert UNB400). Dehydrated slices were then processed by grinder device (IKA, MF 10 basic) to fine powder, and subsequently stored in moisture-controlled ziplock bags at $4{ }^{\circ} \mathrm{C}$. Ethanolic ginger extract was prepared by mixing $2 \mathrm{~g}$ of ginger powder in the $100 \mathrm{~mL}$ of absolute ethanol. The mixture was processed for $30 \mathrm{~min}$ at $85^{\circ} \mathrm{C}$. The prepared extract was filtered by Whatman No. 1 filter paper. Dry extract $(5 \mathrm{~g})$ was dissolved in $10 \mathrm{~mL}$ of methanol solvent and sonicated for $30 \mathrm{~min}$ at $15^{\circ} \mathrm{C}$. Constituents of the extract were quantified by HPLC (Smartline, Knauer, Germany) method [32]. The contents of bioactive components were determined in the extract and the concentration of 6-gingerol, 8-gingerol, 10-gingerol, and 6-shogaol was 6163.1, 802.8, 783.9, and $839.9 \mathrm{mg} / \mathrm{kg}$ ginger (on dry weight basis), respectively. Nutrient compositions and total phenolic content of ginger root powder were analyzed according to standard method, Association of Official Analytical Chemists (AOAC) [33] and Nemati et al. [34], respectively and the results are given in Table 2. 
Table 2. Nutrient composition of ginger powder (\% DM) used in the experiment.

\begin{tabular}{cc}
\hline Item & Level (\%) \\
\hline Dry matter, DM & 88.5 \\
Phenol, component (g/100 gr) & 0.703 \\
Crude protein & 5.5 \\
Ash & 11.75 \\
Organic matter, OM & 88.25 \\
Ether extract, EE & 1.35 \\
Neutral detergent fiber, NDF & 7.5 \\
Acid detergent fiber, ADF & 4.5 \\
Natural detergent soluble fiber, NDS & 92.5 \\
Acid Detergent soluble fiber, ADS & 95.5 \\
\hline
\end{tabular}

\subsection{Measurement of Productive Performance and Egg Quality}

In this study, egg production was recorded daily; however, feed consumption and egg weight [25] were recorded weekly. Moreover, feed efficiency was calculated by dividing the total feed intake by total egg mass during each period. The feed conversion ratio (FCR) [35] was expressed as kilograms of feed consumed per kilogram of egg produced. Six eggs (per replicate) were randomly selected to determine the traits related to the characteristics of quail eggs at $0,2,4,6$, and 8 weeks. Egg length and width were measured with a $0.01 \mathrm{~mm}$ digital caliper (Mitutoyo). For Haugh unit measurements six eggs were weighed and then cracked separately. Albumen heights of three near yolk areas were measured with a $0.01 \mathrm{~mm}$ digital caliper. The Haugh unit [35] was calculated using egg weight and albumen height data of each 6 egg. Furthermore, the yolk height and width were measured by $0.01 \mathrm{~mm}$ digital caliper. For calculation of yolk to albumen ratio as well as yolk and albumen percentages, yolk and albumen were carefully separated from each other and subsequently weighed by $0.001 \mathrm{~g}$ digital scale (A\&D N92) [36]. For color measurements using Roche color fan, eggs were individually broken onto a flat surface and then color was recorded [35]. Egg shell thickness was measured using a $0.01 \mathrm{~mm}$ micrometer at three different points. Average of three points was considered as final thickness of each eggshell. The eggshell percentages were calculated using washed and dried eggshell weights [35]. For $\mathrm{pH}$ analysis, yolk and albumen were completely mixed with a glass rod prior to measurement separately (pH meter; Hanna 211, Woonsocket, RI, USA) [34].

\subsection{Blood Biochemical Parameters Analysis}

At the end of the experiment, two birds from each replicate were randomly picked up for slaughter (6 birds per treatment). Blood samples were collected from the neck vein of the birds using sterilized needles and then centrifuged for $15 \mathrm{~min}$ at $3000 \mathrm{rpm}$ to separate the serum. The collected serum was stored at $-20^{\circ} \mathrm{C}$ for the analysis of glucose (Catalog No: 117500), albumin (Catalog No: 5017) and total protein (Catalog No: 128500), cholesterol (Catalog No: 110500), and triglycerides (Catalog No: 132500). Blood biochemical parameters were measured by a spectrophotometric analysis, using commercially available kits (Pars Azmun Diagnostic, Tehran, Iran).

\subsection{Antioxidant Status}

Ferric reducing antioxidant power assay was used to assess the total antioxidant capacity (TAC) of blood samples [37]. TAC was quantified by the reaction of phenanthroline and $\mathrm{Fe}^{2+}$ using a spectrophotometer at $520 \mathrm{~nm}$. TAC is defined as the amount of antioxidants required to increase the absorbance by 0.01 , in $1 \mathrm{~mL}$ of blood sample at $37^{\circ} \mathrm{C}$. Concentration of MDA in the serum, as an index of lipid peroxidation and oxidative stress, was determined using the thiobarbituric acid reactive substances (TBARS) method [37]. The principle is that TBARS reacts with MDA to form a stable pink color that could be measured spectrophotometrically at $532 \mathrm{~nm}$. The values of MDA were expressed as $(\mathrm{nmol} / \mathrm{mL})$. 


\subsection{Statistical Analysis}

Data of production performance and egg quality were subjected to one-way analysis of variance (ANOVA) using MIXED procedure (Repeated Measurement), SAS (version 9) as a completely randomized design [38]. Tukey multiple comparison test was used to compare the averages at a 5\% confidence level. The Shapiro-Wilk and Levene tests were used for model assumptions of homogeneity of variance and normality, respectively. The percentage data including egg mass, egg production rate, yolk index, egg yolk, eggshell and albumen relative weight, and egg shape were transformed by arcsine of the square root before analysis to achieve homogeneity of variance. No statistical difference was observed between the two sets of data thus results of statistical analysis on the original data are presented in this article.

The statistical design model is as follows:

$$
Y_{i j k m}=\mu+T_{i}+W_{j}+T W_{i j}+\varnothing k_{(j i)}+E_{i j k m} .
$$

In which $Y_{\mathrm{ijkm}}$ is observed parameters, $\mu$ is the mean of population, $T_{\mathrm{i}}$ is the treatment effect, $W_{j}$ is the time effect, $\mathrm{TW}_{\mathrm{ij}}$ is the treatment and time interactions, $\varnothing \mathrm{k}_{(\mathrm{ji})}$ is the random factor (bird), and $\mathrm{E}_{\mathrm{ijkm}}$ are residual effects.

Data of blood biochemical parameters and immune response were subjected to oneway ANOVA (general linear model (GLM) procedure), SAS following the statistical model. Comparison of means was performed using Duncan test at the confidence level of $5 \%$. A level of $p<0.05$ was used as the criterion for statistical significance.

$$
Y_{i j}=\mu+T_{i}+E_{i j} .
$$

In which $Y_{\mathrm{ijk}}$ is observed parameters (dependent variable), $\mu$ is the mean of population, $T_{i}$ is the treatment effect and $E_{i j}$ are residual effects.

\section{Results}

\subsection{Productive Performance}

The effect of dietary supplementation with natural additives of ginger powder on the productive performance is presented in Table 3. The results showed that the experimental treatments had no significant effect on egg production rate among the treatments during the experimental period $(p>0.05)$. Egg mass and egg weight were not significantly affected by the level of ginger powder used $(p>0.05)$. As shown in Table 3, addition of different levels of ginger significantly reduced feed intake during the whole experimental period $(p<0.05)$ compared with the control treatment. Ginger powder had dose-dependent effect since highest concentration of $1.5 \mathrm{~g} / \mathrm{kg}$ of diet was most the potent treatment. The effect of treatment and time interaction was insignificant on the feed intake, egg weight and egg mass $(p>0.05)$. Nonetheless, the treatment $x$ time interaction was significant on the FCR $(p<0.05)$. According to our results, Table 3, GP supplemented diet reduced FCR compared with the control group during experiment period $(p<0.05)$. High levels of ginger powder at $1.5 \mathrm{~g} / \mathrm{kg}$ level decreased FCR compared with other groups. The experimental treatments significantly reduced FCR during breeding weeks. Moreover, the effect of time on the FCR was also significant. 
Table 3. Effects of ginger powder supplementation on productive performance in Japanese quails.

\begin{tabular}{|c|c|c|c|c|c|c|}
\hline \multicolumn{2}{|c|}{ Item } & $\begin{array}{l}\text { Feed Intake } \\
\text { (g/day) }\end{array}$ & $\begin{array}{c}\text { Feed Conversion } \\
\text { Ratio (g:g) }\end{array}$ & $\begin{array}{c}\text { Egg Production } \\
\text { Rate }(\%)\end{array}$ & Egg Weight (g) & Egg Mass (\%) \\
\hline \multicolumn{7}{|l|}{ Treat } \\
\hline Control & & $33.87^{\mathrm{a}}$ & 3.03 & 92.99 & 12.01 & 11.16 \\
\hline GP0.5 & & $32.93^{b}$ & 2.88 & 94.10 & 12.13 & 11.41 \\
\hline GP1.0 & & $32.19^{c}$ & 2.77 & 94.42 & 12.31 & 11.62 \\
\hline GP1.5 & & $31.33^{d}$ & 2.72 & 94.77 & 12.15 & 11.51 \\
\hline SEM & & 0.17 & 0.02 & 1.19 & 0.13 & 0.13 \\
\hline Week 0 & & 34.02 & 2.99 & 93.87 & 12.12 & 11.37 \\
\hline \multicolumn{7}{|c|}{ Time, $\mathrm{w}$} \\
\hline Week 2 & & $34.21^{\mathrm{a}}$ & 2.95 & 94.51 & $12.25^{\mathrm{a}}$ & $11.58^{a}$ \\
\hline Week 4 & & $32.13^{b}$ & 2.78 & 94.91 & $12.17^{\mathrm{a}}$ & $11.54^{\mathrm{a}}$ \\
\hline Week 6 & & $32.06^{\mathrm{b}}$ & 2.85 & 93.84 & $11.99^{b}$ & $11.25^{b}$ \\
\hline Week 8 & & $31.93^{b}$ & 2.82 & 93.03 & $12.18^{\mathrm{a}}$ & $11.33^{b}$ \\
\hline SEM & & 0.21 & 0.01 & 0.82 & 0.08 & 0.08 \\
\hline \multicolumn{7}{|c|}{ treat $\times$ Time } \\
\hline Control & Week 2 & 34.71 & $3.02^{a, b}$ & 93.92 & 12.22 & 11.48 \\
\hline Control & Week 4 & 34.45 & $3.01^{a, b, c}$ & 94.10 & 12.13 & 11.41 \\
\hline Control & Week 6 & 33.66 & $3.1^{\mathrm{a}}$ & 92.32 & 11.77 & 10.85 \\
\hline Control & Week 8 & 32.68 & $2.99^{a, b, c, d}$ & 91.61 & 11.91 & 10.91 \\
\hline GP0.5 & Week 2 & 34.82 & $3.05^{a, b}$ & 93.21 & 12.26 & 11.42 \\
\hline GP0.5 & Week 4 & 32.11 & $2.81^{\mathrm{d}, \mathrm{e}, \mathrm{f}}$ & 94.46 & 12.08 & 11.39 \\
\hline GP0.5 & Week 6 & 31.94 & $2.85^{b, c, d, e, f}$ & 93.03 & 12.02 & 11.18 \\
\hline GP0.5 & Week 8 & 32.84 & $2.82^{c, d, e, f}$ & 95.71 & 12.15 & 11.63 \\
\hline GP1.0 & Week 2 & 34.05 & $2.89^{b, c, d, e}$ & 95.17 & 12.36 & 11.77 \\
\hline GP1.0 & Week 4 & 31.19 & $2.69^{\mathrm{f}, \mathrm{g}}$ & 94.28 & 12.26 & 11.56 \\
\hline GP1.0 & Week 6 & 32.03 & $2.77^{\mathrm{e}, \mathrm{f}, \mathrm{g}}$ & 94.50 & 12.23 & 11.56 \\
\hline GP1.0 & Week 8 & 31.50 & $2.71 \mathrm{e}, \mathrm{f}, \mathrm{g}$ & 93.75 & 12.37 & 11.59 \\
\hline GP1.5 & Week 2 & 33.25 & $2.85^{b, c, d, e, f}$ & 95.71 & 12.15 & 11.65 \\
\hline GP1.5 & Week 4 & 30.80 & $2.61^{\mathrm{g}}$ & 96.78 & 12.19 & 11.80 \\
\hline GP1.5 & Week 6 & 30.58 & $2.68^{f, g}$ & 95.53 & 11.94 & 11.42 \\
\hline GP1.5 & Week 8 & 30.69 & $2.74^{e, f, g}$ & 91.07 & 12.31 & 11.19 \\
\hline SEM & & 0.42 & 0.03 & 1.64 & 0.16 & 0.17 \\
\hline \multicolumn{7}{|c|}{ Probability } \\
\hline \multicolumn{2}{|c|}{ Treat } & $>0.0001$ & $>0.0001$ & 0.74 & 0.48 & 0.16 \\
\hline \multicolumn{2}{|c|}{ Time } & $>0.0001$ & $>0.0001$ & 0.32 & 0.001 & 0.007 \\
\hline \multicolumn{2}{|c|}{ Treat $\times$ Time } & 0.07 & 0.01 & 0.23 & 0.41 & 0.06 \\
\hline
\end{tabular}

Different letters $\left({ }^{a}, \mathrm{~b}, \mathrm{c}, \mathrm{d}, \mathrm{e}, \mathrm{f}\right.$ or $\left.{ }^{\mathrm{g}}\right)$ after the means within a column indicate significant differences among treatments $(p<0.05)$.

\subsection{Quality Traits of Eggs}

The effects of diet supplementation with different levels of ginger powder on qualitative traits of eggs are given in Table 4 . The results showed that the effects of ginger powder on egg weight, shape index, albumen weight, shell weight, albumen, yolk and shell percentage, yolk $\mathrm{pH}$, and shell thickness and strength were insignificant $(p>0.05)$. Ginger supplementation improved yolk index; however, it did not increase yolk weight compared with the control treatment $(p>0.05)$. Nonetheless, effect of time on yolk index was significant $(p<0.05)$. The highest yolk color was related to the highest level of ginger in the diet. The effect of treatment $x$ time interaction, as shown in Table 5 , were significant on yolk color, albumen height and albumen index during experimental period $(p<0.05)$. The albumen and yolk $\mathrm{pH}$ were significantly reduced by ginger powder experimental diet compared with the control treatment $(p<0.05)$. Ginger diet improved Haugh unit relative to control group $(p<0.05)$, but egg specific gravity (ESG) did not differ (Table 4 ). 
Table 4. Effect of different level of ginger root powder on egg quality of Japanese quails.

\begin{tabular}{|c|c|c|c|c|c|c|c|c|}
\hline \multirow{3}{*}{ Traits } & \multicolumn{5}{|c|}{ Experimental Diets } & \multicolumn{3}{|c|}{$p$ Value } \\
\hline & \multicolumn{4}{|c|}{ Ginger Powder (g/kg of Diet) } & \multirow{2}{*}{ SEM } & \multirow{2}{*}{ Treatment } & \multirow{2}{*}{ Time } & \multirow{2}{*}{$\begin{array}{l}\text { Treatment } \\
\times \text { Time }\end{array}$} \\
\hline & 0 & 0.5 & 1 & 1.5 & & & & \\
\hline Shape index \% & 128.97 & 130.25 & 253.90 & 122.66 & 62.09 & 0.43 & 0.45 & 0.43 \\
\hline Albumen index \% & 10.36 & 10.74 & 10.89 & 10.79 & 0.23 & 0.46 & 0.01 & 0.009 \\
\hline Yolk index \% & $44.77^{\mathrm{c}}$ & $47.02^{\mathrm{a}}$ & $46.16^{\mathrm{a}, \mathrm{b}}$ & $45.17^{b, c}$ & 0.54 & 0.005 & $>0.001$ & 0.13 \\
\hline Albumen height (mm) & $3.81^{\mathrm{b}}$ & $3.99^{\mathrm{a}}$ & $4.11^{\mathrm{a}}$ & $4.04^{\mathrm{a}}$ & 0.04 & 0.004 & 0.21 & 0.02 \\
\hline Haugh unit & $84.88^{b}$ & $86.06^{\mathrm{a}}$ & $86.62^{\mathrm{a}}$ & $86.27^{\mathrm{a}}$ & 0.24 & 0.003 & 0.13 & 0.07 \\
\hline Albumen weight & 7.45 & 7.49 & 7.52 & 7.53 & 0.09 & 0.93 & 0.49 & 0.15 \\
\hline Yolk colour & $4.25^{b}$ & $4.45^{b}$ & $4.70^{\mathrm{a}}$ & $4.75^{\mathrm{a}}$ & 0.08 & 0.004 & $>0.001$ & $>0.001$ \\
\hline Shell weight (g) & 0.965 & 0.966 & 0.987 & 0.989 & 0.01 & 0.56 & 0.59 & 0.98 \\
\hline Albumen percentage \% & 59.92 & 60.80 & 60.14 & 60.41 & 0.36 & 0.39 & 0.11 & 0.29 \\
\hline Yolk percentage \% & 32.31 & 31.35 & 31.95 & 31.64 & 0.30 & 0.20 & 0.03 & 0.44 \\
\hline Shell percentage $\%$ & 7.76 & 7.84 & 7.90 & 7.93 & 0.11 & 0.73 & 0.59 & 0.29 \\
\hline Albumen to yolk & 0.539 & 0.515 & 0.531 & 0.524 & 0.008 & 0.26 & 0.03 & 0.33 \\
\hline Yolk weight (g) & 4.02 & 3.86 & 3.99 & 3.94 & 0.05 & 0.21 & 0.08 & 0.70 \\
\hline Yolk pH & $5.87^{\mathrm{a}}$ & $5.84^{b}$ & $5.81^{b}$ & $5.85^{b}$ & 0.01 & 0.02 & $>0.001$ & 0.02 \\
\hline Albumen $\mathrm{pH}$ & $8.91^{\mathrm{a}}$ & $8.78^{b}$ & $8.77^{b}$ & $8.83^{\mathrm{b}}$ & 0.02 & 0.01 & $>0.001$ & 0.009 \\
\hline Egg specific gravity $\left(\mathrm{g} / \mathrm{cm}^{3}\right)$ & 1.0740 & 1.0745 & 1.0748 & 1.0750 & 0.0006 & 0.72 & 0.60 & 0.97 \\
\hline Shell thickness $(\mathrm{mm} \times 10)^{2}$ & 20.61 & 20.67 & 20.29 & 20.76 & 0.35 & 0.80 & 0.005 & 0.51 \\
\hline Shell strength $\left(\mathrm{hg} / \mathrm{cm}^{2}\right)$ & 19.51 & 19.71 & 19.86 & 19.94 & 0.28 & 0.73 & 0.59 & 0.97 \\
\hline
\end{tabular}

Different letters $\left({ }^{a, b}\right.$ or $\left.^{c}\right)$ after the means within a row indicate significant differences among treatments $(p<0.05)$.

Table 5. Effect of treatment and time Interaction on egg albumen and yolk traits in Japanese quails fed different level of ginger root powder.

\begin{tabular}{|c|c|c|c|c|c|c|}
\hline Treat & Time (Week) & Albumen Index & Albumen Height (mm) & Yolk Colour & Yolk pH & Albumen pH \\
\hline Control & 2 & $10.38^{a, b}$ & $3.71^{\mathrm{b}}$ & $3.87^{\mathrm{d}}$ & $5.91^{\mathrm{a}, \mathrm{b}}$ & $8.99^{a, b}$ \\
\hline Control & 4 & $9.75^{b}$ & $3.68^{b}$ & $4.56^{\mathrm{b}, \mathrm{c}}$ & $5.85^{\mathrm{a}, \mathrm{b}, \mathrm{c}, \mathrm{d}}$ & $9.10^{\mathrm{a}}$ \\
\hline Control & 6 & $10.36^{\mathrm{a}, \mathrm{b}}$ & $3.90^{\mathrm{a}, \mathrm{b}}$ & $4.35^{\mathrm{b}, \mathrm{c}, \mathrm{d}}$ & $5.84^{\mathrm{a}, \mathrm{b}, \mathrm{c}, \mathrm{d}}$ & $8.81^{\mathrm{c}, \mathrm{d}, \mathrm{e}, \mathrm{f}}$ \\
\hline Control & 8 & $10.95^{\mathrm{a}, \mathrm{b}}$ & $3.94^{\mathrm{a}, \mathrm{b}}$ & $4.20^{b, c, d}$ & $5.89^{a, b, c}$ & $8.75^{\mathrm{c}, \mathrm{d}, \mathrm{e}, \mathrm{f}}$ \\
\hline GP0.5 & 2 & $9.98^{a, b}$ & $4.01^{\mathrm{a}, \mathrm{b}}$ & $4.20^{\mathrm{b}, \mathrm{c}, \mathrm{d}}$ & $5.81^{b, c, d}$ & $8.73^{\mathrm{e}, \mathrm{f}, \mathrm{g}}$ \\
\hline GP0.5 & 4 & $11.09^{a, b}$ & $4.001^{\mathrm{a}, \mathrm{b}}$ & $4.12^{\mathrm{c}, \mathrm{d}}$ & $5.82^{\mathrm{a}, \mathrm{b}, \mathrm{c}, \mathrm{d}}$ & $8.91^{\mathrm{a}, \mathrm{b}, \mathrm{c}, \mathrm{d}}$ \\
\hline GP0.5 & 6 & $10.86^{a, b}$ & $3.91^{a, b}$ & $4.56^{\mathrm{b}, \mathrm{c}, \mathrm{d}}$ & $5.85^{\mathrm{a}, \mathrm{b}, \mathrm{c}, \mathrm{d}}$ & 8.74 e,f,g \\
\hline GP0.5 & 8 & $11.02^{a, b}$ & $4.04^{\mathrm{a}, \mathrm{b}}$ & $4.91^{\mathrm{a}, \mathrm{b}}$ & $5.88^{a, b, c}$ & 8.72 e,f,g \\
\hline GP1.0 & 2 & $10.99 \mathrm{a}, \mathrm{b}$ & $4.26^{\mathrm{a}}$ & $4.29^{b, c, d}$ & $5.76^{\mathrm{d}}$ & $8.76^{\mathrm{c}, \mathrm{d}, \mathrm{e}, \mathrm{f}}$ \\
\hline GP1.0 & 4 & $10.33^{a, b}$ & $3.98^{a, b}$ & $4.41^{\mathrm{b}, \mathrm{c}, \mathrm{d}}$ & $5.81^{\mathrm{a}, \mathrm{b}, \mathrm{c}, \mathrm{d}}$ & $8.90^{\mathrm{a}, \mathrm{b}, \mathrm{c}, \mathrm{e}}$ \\
\hline GP1.0 & 6 & $11.50^{\mathrm{a}}$ & $4.25^{\mathrm{a}}$ & $4.54^{b, c, d}$ & $5.81^{\mathrm{a}, \mathrm{b}, \mathrm{c}, \mathrm{d}}$ & $8.72^{\mathrm{d}, \mathrm{f}, \mathrm{g}}$ \\
\hline GP1.0 & 8 & $10.71^{\mathrm{a}, \mathrm{b}}$ & $3.94^{\mathrm{a}, \mathrm{b}}$ & $5.56^{\mathrm{a}}$ & $5.86^{\mathrm{a}, \mathrm{b}, \mathrm{c}, \mathrm{d}}$ & $8.70^{f}$ \\
\hline GP1.5 & 2 & $10.24^{\mathrm{a}, \mathrm{b}}$ & $4.05^{a, b}$ & $4.35^{b, c, d}$ & $5.85^{\mathrm{a}, \mathrm{b}, \mathrm{c}, \mathrm{d}}$ & $8.81^{b, c, d, e, f}$ \\
\hline GP1.5 & 4 & $10.45^{\mathrm{a}, \mathrm{b}}$ & $4.04^{\mathrm{a}, \mathrm{b}}$ & $4.50^{\mathrm{b}, \mathrm{c}, \mathrm{d}}$ & $5.79^{\mathrm{c}, \mathrm{d}}$ & $8.89^{a, b, c, d, e, f}$ \\
\hline GP1.5 & 6 & $11.26^{\mathrm{a}, \mathrm{b}}$ & $4.06^{\mathrm{a}, \mathrm{b}}$ & $4.58^{b, c, d}$ & $5.84^{\mathrm{a}, \mathrm{b}, \mathrm{c}, \mathrm{d}}$ & $8.76^{\mathrm{c}, \mathrm{d}, \mathrm{e}, \mathrm{f}}$ \\
\hline GP1.5 & 8 & $10.87^{a, b}$ & $4.02^{a, b}$ & $5.56^{\mathrm{a}}$ & $5.92^{\mathrm{a}}$ & $8.86^{\mathrm{b}, \mathrm{c}, \mathrm{d}, \mathrm{e}, \mathrm{f}}$ \\
\hline SEM & & 0.34 & 0.08 & 0.13 & 0.02 & 0.04 \\
\hline$p$ value & & 0.009 & 0.02 & 0.001 & 0.02 & 0.009 \\
\hline
\end{tabular}

Different letters $\left(\mathrm{a}, \mathrm{b}, \mathrm{c}, \mathrm{d}, \mathrm{e}, \mathrm{f}\right.$ or $\left.^{\mathrm{g}}\right)$ after the means within a column indicate significant differences among treatments $(p<0.05)$.

\subsection{Blood Parameters and Egg Yolk Phenolic Compounds}

The effect of experimental diets on blood parameters of animals are presented in Table 6 and Figure 1. The results revealed that supplementation of ginger powder in the diet had significant effect on the level of triacylglycerol $(p<0.05)$. Nevertheless, serum albumin, cholesterol, glucose, MDA, and TAC were not affected by the diet $(p>0.05)$. Level of serum TAC only numerically elevated, while MDA level was reduced in birds fed medium level of ginger powder compared with the control group. The effect of experimental treatments on phenolic compounds of the yolk, as shown in Figure 1, was 
significant $(p<0.05)$. Highest concentration of ginger powder $(1.5 \mathrm{~g} / \mathrm{kg}$ diet $)$ was the most effective treatment in stimulating the production of phenolic.

Table 6. Biochemical parameters in blood serum of Japanese quail fed diets with ginger powder supplementation.

\begin{tabular}{|c|c|c|c|c|c|}
\hline Treatments & $\begin{array}{l}\text { Protein } \\
\left(\mathrm{g} \mathrm{dL}^{-1}\right)\end{array}$ & $\begin{array}{l}\text { Albumin } \\
\left(\mathrm{g} \mathrm{dL}^{-1}\right)\end{array}$ & $\begin{array}{l}\text { Triacylglycerol } \\
\quad\left(\mathrm{mg} \mathrm{dL}^{-1}\right)\end{array}$ & $\begin{array}{l}\text { Cholesterol } \\
\left(\mathrm{mg} \mathrm{dL}^{-1}\right)\end{array}$ & $\begin{array}{c}\text { Glucose } \\
\left(\mathrm{mg} \mathrm{dL}^{-1}\right)\end{array}$ \\
\hline Control & 5.80 & 1.60 & $453.1^{a}$ & 243 & 195 \\
\hline Ginger $(0.5 \mathrm{~g} / \mathrm{kg}$ of diet $)$ & 5.70 & 1.43 & $351.8^{b}$ & 247 & 242 \\
\hline Ginger ( $1 \mathrm{~g} / \mathrm{kg}$ of diet $)$ & 5.73 & 1.56 & $336.8^{b}$ & 210 & 173 \\
\hline Ginger $(1.5 \mathrm{~g} / \mathrm{kg}$ of diet $)$ & 6.15 & 1.70 & $342.6^{b}$ & 219 & 221 \\
\hline SEM & 0.28 & 0.1 & 23.03 & 22.18 & 21.80 \\
\hline$p$-value & 0.64 & 0.39 & 0.01 & 0.58 & 0.17 \\
\hline
\end{tabular}

Different letters $\left({ }^{\mathrm{a}}\right.$ or $\left.{ }^{\mathrm{b}}\right)$ after the means within a column indicate significant differences among treatments $(p<0.05)$.

(a)

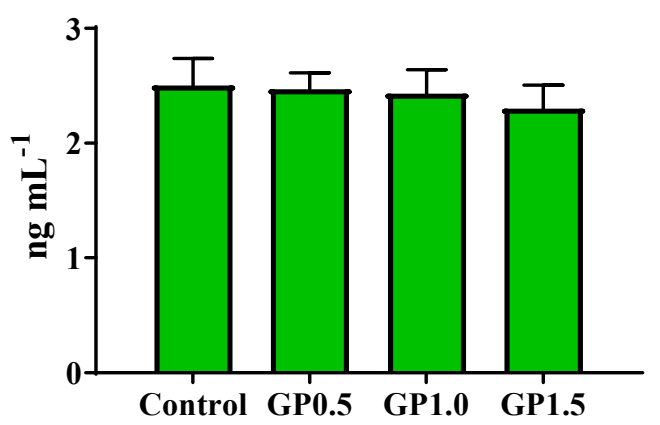

(b)

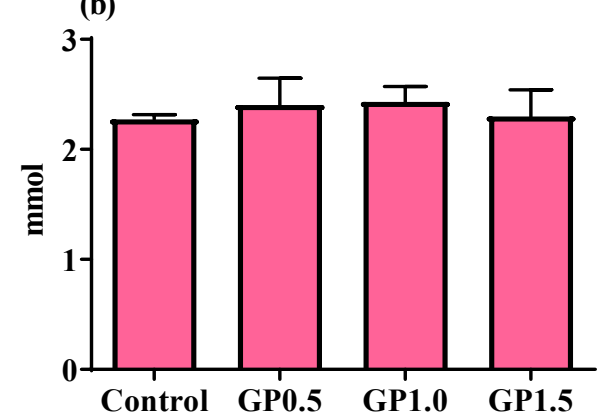

Figure 1. Concentrations of malondialdehyde (MDA) (a) and total antioxidant capacity (TAC) (b) in Japanese quails fed different levels of GP. Values (means \pm SEM) within the same week with uncommon letters are significantly $(p<0.05)$ different.

\section{Discussion}

In general, inclusion of ginger powder in the diet of birds was effective on various productive parameters. In this experiment, production rate and egg mass were not influenced by the treatments, while feed intake and FCR decreased when birds received increasing levels of ginger powder. In agreement to our results, previous findings confirmed that dietary supplementation with ginger root improved FCR in broiler chickens [39] and decreased feed intake in guinea fowl [40]. Furthermore, ginger supplements had no adverse effect on the palatability of broiler feeds [39] and improved the digestibility of dry matter in guinea fowl [40]. Contrarily, Damaziak et al. [29] did not observe any positive effect of the ginger root on egg production rate in laying hens. However, findings of our study were not in agreement with the handful studies showing the insignificant effect of ginger powder [41] or ginger extract dietary supplementation [42] on the FCR. Akbarian et al. reported that using different levels of ginger $(0.25,0.5$ and $0.75 \mathrm{~g} / 100 \mathrm{~g}$ of diet) in laying hens during 30 weeks had insignificant effect on FI and FCR [43]. The disparity of this study with previous research results could be due to differences in ginger source, processing methods as well as poultry species [42,44]. Ginger contains many active compounds (e.g., brunel, camphon, limonene, humolin, gingerol, gingeron, gingerdiol, shogaols, some phenolic ketone derivatives, volatile oils, alkaloids, saponins, and flavonoids) [45] that could stimulate feed digestion and the digestive enzymes, thus increasing FI and FCR [38]. In the same way Platel and Srinivasan [46] stated that ginger enhanced the activity of pancreatic lipase, amylase, trypsin chymotrypsin, and bile acid secretion in albino rats. In fact, these enzymes, bile and biliary bile acids significantly affect the digestion and absorption of nutrients. In accord, Habibi et al. [28] indicated the stimulating effect of ginger root powder $(7.5 \mathrm{~g} / \mathrm{kg}$ of diet) on body weight and weight gain in broiler chicks at 22 days of the experiment. In another study, ginger powder increased production, 
hatchability, reproductive performance, and economic efficiency at a level of $0.05 \mathrm{~g} / \mathrm{kg}$ diet while increasing egg weight and feed intake in Japanese quail [25]. In present study, ginger powder supplemented diet had no effect on egg production, egg weight, and total egg mass among the treatments during the experiment period. Our findings were in line with the results of Wen at al. [42] and Herve et al. [47] reporting the insignificant effect of ginger supplemented diet in laying hen and quail. Moreover, Wen et al. concluded that egg weight was improved in ginger powder fed laying hen [47]. The results of studies on the effect of ginger at increasing levels of $0,5,10,15$, and $20 \mathrm{~g} / \mathrm{kg}$ of diet on the performance of laying hens at the age of 27 weeks showed that all laying hens were in good health and no mortality was recorded in the whole period of the experiment. Average egg weight and laying rate were similar in treatments containing ginger powder. Egg mass was positively affected by the treatments compared with the control group, which can be related to the positive effect of ginger powder on laying rate as well as egg weight [48]. In contrast to the current quail study, egg production rate was increased in ginger extract/powder fed laying hen [48,49] alone or in combination with medicinal herbs [27]. This means that the beneficial effect of ginger on performance depends on the bird species, dosage of ginger, and its derivatives and interaction with other dietary components. However, information about mechanism of action of ginger intake are scarce [50].

In this study ginger powder was beneficial on the reducing the blood triacylglyceride levels yet its effects were not significant on serum cholesterol and glucose levels. Other serum parameters including albumin, and protein were not significantly affected by ginger powder $(p>0.05)$. Consistent with these results, studies have shown that diet supplementation with ginger extract at 0.4 and $0.6 \mathrm{mg} / \mathrm{g}$ of diet, significantly decreased glucose, triglyceride, and cholesterol levels [51]. Akhany et al. [52] concluded that ginger extract significantly reduced blood glucose levels and increased insulin levels. Some of the essential minerals (calcium, zinc, potassium, manganese, and chromium) are related to the mechanism of insulin release [53]. In another study, ginger at concentrations up to $2 \%$ of the diet reduced cholesterol, triglyceride, and glucose levels in comparison with the control group, while the serum protein was not affected by the experimental treatments [38]. Ginger has previously shown strong anti-lipidemic effect on serum cholesterol and triglyceride levels [54]; hence, its mode of action may be related to the inhibition of cholesterol synthesis (e.g., $\beta$-hydroxy- $\beta$-methylglutaryl coenzyme A (HMG-CoA) [51]. Correspondingly, ginger is a potent HMGR-inhibiting drug, known to cause liver-specific inhibition of cholesterol synthesis [55]. In addition, other reports showed that diabetic therapy with insulin helps in reducing the plasma triglycerides by affecting lipoprotein lipase levels [56]. Ginger has insulin-stimulating effect which could reduce plasma triglycerides [56]. Previous studies stated that phenols and flavonoids act as potent antioxidants [57]. Khalifa and Noseer [58] revealed that eggs produced by quail supplemented with combined ginger powder and probiotics had the lowest total cholesterol content in serum and yolk compared with the control, along with an increase in high-density lipoprotein (HDL) and decrease of low-density lipoprotein (LDL). Herve et al. [59] showed that total cholesterol and triglycerides, transaminases, and MDA decreased in quails supplemented with ginger essential oil at 50,100, and $150 \mu \mathrm{L} / \mathrm{kg}$ body weight.

Haugh unit, albumen height, and yolk index are characterized as main reference associated with egg quality, which influenced by feed additive (e.g., green tea powder) [60]. In this study yolk index, albumen height, and Haugh unit of eggs were increased in diet supplemented with ginger powder. Several studies indicated that ginger supplementation in poultry diets significantly increased antioxidant enzymes as well as TAC and decreased MDA $[22,28,43]$. Improvement of egg yolk index and Haugh unit in the current study may be due to the effect of the phenolic compounds of ginger (gingerols and shagaol) which have antioxidant properties [61]. As discussed earlier, color of the yolk an acceptability and freshness feature of the egg, could be improved by natural products such as carotenoids. In this study, egg yolk color was positively affected by ginger powder consumption $(1.5 \mathrm{mg} / \mathrm{kg})$. However, others have reported the ineffectiveness of fermented 
ginger powder (10 and $50 \mathrm{mg} / \mathrm{kg}$ of diet concentrations) [23] and ginger extract [42] on the yolk color and yolk and albumen percentage. The intensity of egg yolk color depends on the presence and utilization of pigments in the diet, because laying hens have no ability to produce pigments through their biochemical processes [62]. The darker yolk color of eggs from quails received ginger is probably due to the natural pigments found in ginger, including 6-dehydrogingerdione, which causes a deep yellow color [63]. No difference in other quality traits of quail eggs indicates that ginger does not affect the egg shell quality or egg composition (percentage of albumen, yolk, and shell). The results of present experiment consistent with the result of Wen et al. 2019 [42] showing that the use of ginger root as an additive in Japanese quail diet had significant effect on Haugh unit and albumen height yet being ineffective on shell thickness, shell strength, and egg composition percentage. We, in this study, observed concentration dependent potency of ginger powder on many important parameters of fresh egg quality (e.g., Haugh unit, yolk index, and yolk color) in laying quails; however, other variables associated with egg shelf life should be tested for a final statement.

\section{Conclusions}

The results of this study suggest that the inclusion of ginger root powder in Japanese quail diet can partially improve the productive performance, antioxidant status, and blood parameters. Moreover, ginger could improve yolk color and albumen quality expressed in Haugh units. The effects on the quail production performance seemed to be dose dependent and ginger at the highest tested level $(1.5 \mathrm{~g} / \mathrm{kg}$ of ginger powder) was most effective treatment. However, further studies are needed to conclude on the effect of ginger on quality of the poultry products as well as its mechanism of action.

Author Contributions: Conceptualization, Z.N.; methodology, Z.N., Z.M., and K.A.; software, Z.N. and Z.M.; validation Z.N. and Z.M.; formal analysis, Z.N. and K.A; investigation and resources, Z.M. and Z.N.; data curation, Z.N.; writing-original draft preparation, Z.M and Z.N; writing-review and editing, A.R. and M.B.; project administration, Z.N.; funding acquisition, Z.N. and A.R. All authors have read and agreed to the published version of the manuscript.

Funding: This research was funded by The University of Tabriz (grant number: 11.934).

Institutional Review Board Statement: The study was conducted according to the guidelines of the National norms and standard for conducting medicinal research in Iran, and approved by the Research Bioethics Committee of Tabriz University (Approved number: IR.TABRIZU.REC.1399.032).

Informed Consent Statement: Not applicable.

Data Availability Statement: Qualified researchers can obtain the data from the corresponding author. The data are not publicly available due to privacy concerns imposed by the RBCT ethical principles.

Conflicts of Interest: The authors declare no conflict of interest.

\section{References}

1. Castanon, J. History of the Use of Antibiotic as Growth Promoters in European Poultry Feeds. Poult. Sci. 2007, 86, $2466-2471$. [CrossRef]

2. Nemati, Z.; Mohammadi, R. The effects of different levels of dietary garlic powder on productive performance, egg quality traits and blood parameters of laying hens. J. Anim. Prod. 2017, 19, 657-670.

3. Zeng, Z.; Zhang, S.; Wang, H.; Piao, X. Essential oil and aromatic plants as feed additives in non-ruminant nutrition: A review. J. Anim. Sci. Biotechnol. 2015, 6, 7-17. [CrossRef]

4. Ravindran, P.; Nirmal, B. Ginger: The genus Zingiber. In Medicinal and Aromatic Plant-Industrial Profile; CRC Press: Boca Raton, FL, USA, 2005.

5. Food and Agriculture Organization of the United Nations, Statistics Division. Ginger production in 2016, Crops/ Regions/ World/ Production/ Quantity (from pick lists). 2017. Available online: http://www.fao.org/faostat/en/\#data/QC/visualize (accessed on 2 March 2021).

6. Policegoudra, R.; Aradhya, S. Biochemical changes and antioxidant activity of mango ginger (Curcuma amada Roxb.) rhizomes during postharvest storage at different temperatures. Postharvest Biol. Technol. 2007, 46, 189-194. [CrossRef] 
7. Dieumou, F.; Teguia, A.; Kuiate, J.; Tamokou, J.; Fonge, N.; Dongmo, M. Effects of ginger (Zingiber officinale) and garlic (Allium sativum) essential oils on growth performance and gut microbial population of broiler chickens. Livest. Res. Rural Dev. 2009, 21, 23-32.

8. Arablou, T.; Aryaeian, N.; Valizadeh, M.; Sharifi, F.; Hosseini, A.; Djalali, M. The effect of ginger consumption on glycemic status, lipid profile and some inflammatory markers in patients with type 2 diabetes mellitus. Int. J. Food Sci. Nutr. 2013, 65, 515-520. [CrossRef] [PubMed]

9. Chakraborty, D.; Mukherjee, A.; Sikdar, S.; Paul, A.; Ghosh, S.; Khuda-Bukhsh, A.R. [6]-Gingerol isolated from ginger attenuates sodium arsneenite induced oxidative stress and plays a corrective role in improving insulin signaling in mice. Toxicol. Lett. 2012, 210, 34-43. [CrossRef] [PubMed]

10. Vishwakarma, S.L.; Pal, S.C.; Kasture, V.S.; Kasture, S.B. Anxiolytic and antiemetic activity of Zingiber officinale. Phytother. Res. 2002, 16, 621-626. [CrossRef] [PubMed]

11. Ernst, E.; Pittler, M.H. Efficacy of ginger for nausea and vomiting: A systematic review of randomized clinical trials. Br. J. Anaesth. 2000, 84, 367-371. [CrossRef]

12. Grzanna, R.; Lindmark, L.; Frondoza, C.G. Ginger-An Herbal Medicinal Product with Broad Anti-Inflammatory Actions. J. Med. Food 2005, 8, 125-132. [CrossRef] [PubMed]

13. Al-Amin, Z.M.; Thomson, M.; Al-Qattan, K.K.; Peltonen-Shalaby, R.; Ali, M. Anti-diabetic and hypolipidaemic properties of ginger (Zingiber officinale) in streptozotocin-induced diabetic rats. Br. J. Nutr. 2006, 96, 660-666. [CrossRef] [PubMed]

14. Verma, S.K.; Singh, M.; Jain, P.; Bordia, A. Protective effect of ginger, Zingiber officinale Rosc on experimental atherosclerosis in rabbits. Indian J. Exp. Biol. 2004, 42, 736-738.

15. Bosisio, E. Effect of the flavanolignans of Silybum marianum L. On lipid peroxidation in rat liver microsomes and freshly isolated hepatocytes. Pharmacol. Res. 1992, 25, 147-165. [CrossRef]

16. Vipin, A.V.; Raksha Rao, K.; Kurrey, N.K.; Anu Appaiah, K.A.; Venkateswaran, G. Protective effects of phenolics rich extract of ginger against Aflatoxin B1-induced oxidative stress and hepatotoxicity. Biomed. Pharmacother. 2017, 91, 415-424.

17. Wang, W.; Wang, Z. Studies of commonly used traditional medicine-ginger. Zhongguo Zhong Yao Za Zhi China J. Chin. Mater. Med. 2005, 30, 1569-1573.

18. Gao, Y.; Ozel, M.Z.; Dugmore, T.; Sulaeman, A.; Matharu, A.S. A biorefinery strategy for spent industrial ginger waste. J. Hazard. Mater. 2021, 401, 123400. [CrossRef]

19. Wiastuti, T.; Khasanah, L.U.; Kawiji, W.A.; Manuhara, G.J.; Utami, R. Characterization of active paper packaging incorporated with ginger pulp oleoresin. In Proceedings of the IOP Conference Series: Materials Science and Engineering; IOP Publishing: Bristol, UK, 2016; Volume 107, p. 012057.

20. Al-Shuwaili, M.A.; Ibrahim, E.; Naqi Al-Bayati, M. Effect of dietary herbal plants supplement in turkey diet on performance and some blood biochemical parameters. Glob. J. Biosci. Biotechnol. 2015, 4, 153-157.

21. Yusuf, M.; Hasan, M.; Elnabtiti, A.; Cui, H. Single dose of ginger powder, supported with organic acid or probiotic, maximizes the laying, egg quality hatchability and immune performances of laying Japanese quails. Int. J. Recent Sci. Res. 2015, 6, 6707-6711.

22. Zhang, G.F.; Yang, Z.B.; Wang, Y.; Yang, W.R.; Jiang, S.Z.; Gai, G.S. Effects of ginger root (Zingiber officinale) processed to different particle sizes on growth performance, antioxidant status, and serum metabolites of broiler chickens. Poult. Sci. 2009, 88, 2159-2166. [CrossRef]

23. Incharoen, T.; Yamauchi, K. Production Performance, Egg Quality and Intestinal Histology in Laying Hens Fed Dietary Dried Fermented Ginger. Int. J. Poult. Sci. 2009, 8, 1078-1085. [CrossRef]

24. Najafi, S.; Taherpour, K. Effects of dietary ginger (Zingiber Ofjicinale), cinnamon (Cinnamomum), synbiotic and antibiotic supplementation on performance of broilers. J. Anim. Sci. Adv. 2014, 4, 658-667.

25. Abd El-Galil, K.; Mahmoud, H.A. Effect of ginger roots meal as feed additives in laying Japanese quail diets. J. Am. Sci. 2015, 2, 233-234.

26. Nasiroleslami, M.; Torki, M. Including essential oils of fennel (Foeniculum vulgare) and ginger (Zingiber officinale) to diet and evaluating performance of laying hens, white blood cell count and egg quality characteristics. Adv. Environ. Biol. 2010, 4, 341-346.

27. Ibtisham, F.; Nawab, A.; Niu, Y.; Wang, Z.; Wu, J.; Xiao, M.; An, L. The effect of ginger powder and Chinese herbal medicine on production performance, serum metabolites and antioxidant status of laying hens under heat-stress condition. J. Therm. Biol. 2019, 81, 20-24. [CrossRef]

28. Habibi, R.; Sadeghi, G.; Karimi, A. Effect of different concentrations of ginger root powder and its essential oil on growth performance, serum metabolites and antioxidant status in broiler chicks under heat stress. Br. Poult. Sci. 2014, 55, $228-237$. [CrossRef]

29. Damaziak, K.; Gozdowski, D.; Niemiec, J.; Riedel, J.; Róg, D.; Siennicka, A. Effects of ginger or ginger and thyme extract in laying hens feeding on productive results and eggs quality. Ann. Wars. Univ. Life Sci. SGGW Anim. Sci. 2018, 57, 5-18. [CrossRef]

30. Wang, X.; Wu, S.; Zhang, H.; Yue, H.; Qi, G.; Li, J. Effect of dietary protein sources and storage temperatures on egg internal quality of stored shell eggs. Anim. Nutr. 2015, 1, 299-304. [CrossRef]

31. NRC. Nutrient Requirements of Poultry; National Academy Press: Washington, DC, USA, 1994.

32. Nourbakhsh Amiri, Z.; Najafpour, G.; Mohammadi, M.; Moghadamnia, A. Subcritical water extraction of bioactive compounds from ginger (Zingiber officinale Roscoe). Int. J. Eng. 2018, 31, 1991-2000.

33. AOAC. Official Methods of Analysis; Association of Official Analytical Chemists: Washington, DC, USA, 1990. 
34. Nemati, Z.; Alirezalu, K.; Besharati, M.; Holman, B.; Hajipour, M.; Bohrer, B. The Effect of Dietary Supplementation with Inorganic or Organic Selenium on the Nutritional Quality and Shelf Life of Goose Meat and Liver. Animals 2021, 11, 261. [CrossRef] [PubMed]

35. Nemati, Z.; Ahmadian, H.; Besharati, M.; Lesson, S.; Alirezalu, K.; Domínguez, R.; Lorenzo, J.M. Assessment of Dietary Selenium and Vitamin E on Laying Performance and Quality Parameters of Fresh and Stored Eggs in Japanese Quails. Foods 2020, 9, 1324. [CrossRef]

36. Ahmadian, H.; Nemati, Z.; Karimi, A.; Safari, R. Effect of different dietary selenium sources and storage temperature on enhancing the shelf life of quail eggs. Anim. Prod. Res. 2019, 8, 23-33. (In Persian)

37. Nemati, Z.; Alirezalu, K.; Besharati, M.; Amirdahri, S.; Franco, D.; Lorenzo, J.M. Improving the Quality Characteristics and Shelf Life of Meat and Growth Performance in Goose Fed Diets Supplemented with Vitamin E. Foods 2020, 9, 798. [CrossRef]

38. Mohamed, A.B.; Al-Rubaee, M.A.; Jalil, A.Q. Effect of Ginger (Zingiber officinale) on Performance and Blood Serum Parameters of Broiler. Int. J. Poult. Sci. 2012, 11, 143-146. [CrossRef]

39. Karangiya, V.K.; Savsani, H.H.; Patil, S.S.; Garg, D.D.; Murthy, K.S.; Ribadiya, N.K.; Vekariya, S.J. Effect of dietary supplementation of garlic, ginger and their combination on feed intake, growth performance and economics in commercial broilers. Vet. World 2016, 9, 245-250. [CrossRef] [PubMed]

40. Oso, A.O.; Awe, A.W.; Awosoga, F.G.; Bello, F.A.; Akinfenwa, T.A.; Ogunremi, E.B. Effect of ginger (Zingiber officinale Roscoe) on growth performance, nutrient digestibility, serum metabolites, gut morphology, and microflora of growing guinea fowl. Trop. Anim. Health Prod. 2013, 45, 1763-1769. [CrossRef] [PubMed]

41. Thayalini, K.; Shanmugavelu, S.; Saminathan, P.; SitiMasidayu, M.; Noridayusni, Y.; Zainmuddin, H.; Nurul Akmai, C.; Wong, H. Effects of Cymbopogon citratus leaf and Zingiber officinale rhizome supplementation on growth performance, ileal morphology and lactic acid concentration in broilers. Malays. J. Anim. Sci. 2011, 14, 43-49.

42. Wen, C.; Gu, Y.; Tao, Z.; Cheng, Z.; Wang, T.; Zhou, Y. Effects of Ginger Extract on Laying Performance, Egg Quality, and Antioxidant Status of Laying Hens. Animals 2019, 9, 857. [CrossRef] [PubMed]

43. Akbarian, A.; Golian, A.; Ahmadi, A.S.; Moravej, H. Effects of ginger root (Zingiber officinale) on egg yolk cholesterol, antioxidant status and performance of laying hens. J. Appl. Anim. Res. 2011, 39, 19-21. [CrossRef]

44. PR, S.A.; Prakash, J. Chemical composition and antioxidant properties of ginger root (Zingiber officinale). J. Med. Plants Res. 2010, 4, 2674-2679.

45. Hashimoto, K.; Satoh, K.; Murata, P.; Makino, B.; Sakakibara, I.; Kase, Y.; Ishige, A.; Higuchi, M.; Sasaki, H. Component of Zingiber officinale that Improves the Enhancement of Small Intestinal Transport. Planta Med. 2002, 68, 936-939. [CrossRef]

46. Platel, K.; Srinivasan, K. Influence of dietary spices and their active principles on pancreatic digestive enzymes in albino rats. Food Nahrung 2000, 44, 42-46. [CrossRef]

47. Herve, T.; Raphaël, K.J.; Ferdinand, N.; Victor Herman, N.; Willy Marvel, N.M.; Cyril D'Alex, T.; Laurine Vitrice, F.T. Effects of ginger (Zingiber officinale, Roscoe) essential oil on growth and laying performances, serum metabolites, and egg yolk antioxidant and cholesterol status in laying Japanese quail. J. Vet. Med. 2019, 2019. [CrossRef]

48. Zhao, X.; Yang, Z.B.; Yang, W.R.; Wang, Y.; Jiang, S.Z.; Zhang, G.G. Effects of ginger root (Zingiber officinale) on laying performance and antioxidant status of laying hens and on dietary oxidation stability. Poult. Sci. 2011, 90, 1720-1727. [CrossRef]

49. An, S.; Liu, G.; Guo, X.; An, Y.; Wang, R. Ginger extract enhances antioxidant ability and immunity of layers. Anim. Nutr. 2019, 5 , 407-409. [CrossRef]

50. Kiyama, R. Nutritional implications of ginger: Chemistry, biological activities and signaling pathways. J. Nutr. Biochem. 2020, 86, 108486. [CrossRef]

51. Saeid, J.M.; Mohamed, A.B.; Al-Baddy, M.A. Effect of Aqueous Extract of Ginger (Zingiber officinale) on Blood Biochemistry Parameters of Broiler. Int. J. Poult. Sci. 2010, 9, 944-947. [CrossRef]

52. Akhani, S.P.; Vishwakarma, S.L.; Goyal, R.K. Anti-diabetic activity of Zingiber officinale in streptozotocin-induced type I diabetic rats. J. Pharm. Pharmacol. 2004, 56, 101-105. [CrossRef] [PubMed]

53. Kar, A.; Choudhary, B.K.; Bandyopadhyay, N.G. Preliminary studies on the inorganic constituents of some indigenous hypoglycaemic herbs on oral glucose tolerance test. J. Ethnopharmacol. 1999, 64, 179-184. [CrossRef]

54. Jang, I.; Ko, Y.; Kang, S.; Lee, C. Effect of a commercial essential oil on growth performance, digestive enzyme activity and intestinal microflora population in broiler chickens. Anim. Feed Sci. Technol. 2007, 134, 304-315. [CrossRef]

55. Manju, V.; Viswanathan, P.; Nalini, N. Hypolipidemic Effect of Ginger in 1,2-Dimethyl Hydrazine-Induced Experimental Colon Carcinogenesis. Toxicol. Mech. Methods 2006, 16, 461-472. [CrossRef] [PubMed]

56. Austin, G.E.; Maznicki, E.; Sgoutas, D. Comparison of phosphotungstate and dextran sulfate-Mg2+ precipitation procedures for determination of high density lipoprotein cholesterol. Clin. Biochem. 1984, 17, 166-169. [CrossRef]

57. Pietta, P.-G. Flavonoids as Antioxidants. J. Nat. Prod. 2000, 63, 1035-1042. [CrossRef]

58. Khalifa, M.I.; Noseer, E.A. Cholesterol quality of edible eggs produced by quail fed diets containing probiotic and/or ginger (Zingiber officinale). Livest. Res. Rural Dev. 2019, 31, 165-175.

59. Herve, T.; Raphaël, K.J.; Ferdinand, N.; Vitrice, F.T.L.; Gaye, A.; Outman, M.M.; Marvel, N.M.W. Growth Performance, Serum Biochemical Profile, Oxidative Status, and Fertility Traits in Male Japanese Quail Fed on Ginger (Zingiber officinale, Roscoe) Essential Oil. Vet. Med. Int. 2018, 2018, 1-8. [CrossRef] [PubMed] 
60. Zhang, J.; Zhang, M.; Liang, W.; Geng, Z.; Chen, X. Green tea powder supplementation increased viscosity and decreased lysozyme activity of egg white during storage of eggs from Huainan partridge chicken. Ital. J. Anim. Sci. 2020, 19, 586-592. [CrossRef]

61. Hasan, H.A.; Raauf, A.M.R.; Razik, B.M.A.; Hassan, B.A.R. Chemical Composition and Antimicrobial Activity of the Crude Extracts Isolated from Zingiber Officinale by Different Solvents. Pharm. Anal. Acta 2012, 3, 1-5. [CrossRef]

62. Spasevski, N.; Puvača, N.; Pezo, L.; Tasić, T.; Vukmirović, Đ.; Banjac, V.; Čolović, R.; Rakita, S.; Kokić, B.; Džinić, N. Optimisation of egg yolk colour using natural colourants. Eur. Poult. Sci. 2018, 82, 2018-2035.

63. Ajileye, B.A.; Iteire, A.K.; Arigi, Q.B. Zingiber officinale (ginger) extract as a histological dye for muscle fibers and cytoplasm. Int. J. Med. Sci. 2015, 4, 1445-1448. [CrossRef] 